\title{
Politik Hukum Pidana dalam Perlindungan Korban . Kejahatan Ekonomi di Bidang Perbankan
}

\author{
M. Arief Amrullah
}

\begin{abstract}
As we have seen that corporation te Criminal Code is not the matter of criminal law, so corporation certainly is unreliable criminally. Furthermore if bank is made for crime purpose so the direction will be a white color. Under this condition, it means that there no economical victims normatively on banking. The following would be elaborated the problem above from the political perspective of criminal law.
\end{abstract}

\section{Pendahuluan}

Perkembangan ekonomi dan perbankan yang begitu cepat, demikian juga dengan kebijakan yang diambil oleh pemerintah, tidak selalu sesuai dengan tujuan yang hendak dicapai. Sebagai contọ, kebijakan deregulasi di bidang perbankan yang diawali dengan paket Juni 1983 sampai dengan paket 27 Oktober $1988,{ }^{1}$ telah memunculkan sejumlah persoalan di bidang perbankan. Belum lagi kebijakankebijakan susulan lainnya, seperti petunjuk Presiden Soeharto kepada Menteri Keuangan dan Gubernur Bank Indonesia dalam Sidang Kabinet Terbatas Bidang Ekkuwasbang dan Prodis tanggal 3 September $1997_{i}$ serta Keputusan Presiden Nomor 26 Tahun 1998, tanggal 26 Januari 1998 tentang Jaminan terhadap Kewajiban Pembayaran Bank Umum.

Deregulasi di bidang perbankan tersebut bertujuan untuk membangun kembali kelesuan yang dialami oleh industri perbankan serta untuk memudahkan pendirian bank dan pembukaan bank, sehingga dapat menjangkau ke seluruh

${ }^{1}$ Kebijakan di bidang perbankan yang pertama kali digulirkan pada bulan Juni 1983, adalah dengan membebaskan bank-bank pemerintah menentukan suku bunga deposito yang sebelumnya hanya $B I$ yang berwenang untuk itu. Akibatnya, sejak 1 Juni sampai dengan Maret 1984, deposito pada bank-bank pemerintah meningkat $151 \%$ dibandingkan dengain peningkatan sebesar $18 \%$ dari Agustus 1982 sampai dengan Mei 1983. Lima tahun kemudian disusul dengan paket deregulasi di bidang keuangan, moneter, dan perbankan (KMP) tanggal 27 Oktober 1988. Inilah liberalisasi perbankan yang sangatbesar, sehingga bank-bank boleh membuka cabang-cabang baru, boleh bekerjasama dengan asing untuk membuka bank-bank campuran, di mana sebelumnya kemungkinan tersebut tertutup. Dalam Bachtiar Abdullah, Prospek, No. 34 Tahun 1, 1 Juni 1991, hlm. 1; Widjanarto, Hukum dan Ketentuan Perbankan Indonesia, (Jakarta: Grafiti, 1997), hlm 22. 
wilayah Indonesia. Namun demikian, hal itu belum menjamin ke arah pertumbuhan ekonomi yang tangguh, akan tetapiyang terjadi malah sebaliknya, yaitu seperti dalam kasus kredit macet yang menimpa 16 Bank Umum Swasta Nasional, yang berakibat dilikuidasinya ke 16 bank tersebut pada tanggal 1 November 1997.

Untuk menjamin dana nasabah yang disimpan dalam bank yang terkena likuidasi, pemerintah berkeinginan membantu dengan alasan untuk menjaga stabilitas moneter dan menjaga agar kepercayaan masyarakat terhadap bank tidak berkurang. Untuk itu, pemerintah mengeluarkan Keputusan Presiden Nomor 26 Tahun 1998. Akan tetapi, dalam pelaksanaannya justru membuka peluang terjadinya praktek-praktek yang menyalahi aturan. Bahkan hasil temuan Badan Pemeriksa Keuangan (BPK) menyebutkan, ada pemiljk bank yang me-rush dana yang ada di banknya sendiri, sehingga Bantuan Likuiditas Bank Indonesia (BLBI) yang dikucurkan pun bertambah besar. ${ }^{2}$ Padahal pengucuran BLBI tersebut, adalah untuk menanggulangi bankbank yang mengalami kesulitan likuiditas akibat di-rush oleh nasabahnya. Oleh karena penyaluran BLBI dilakukan melalui mekanisme kliring, maka Bl tidak dapat mengetahui: apakah benar dana BLBI digunakan sepenuhnya untuk menanggulangi rush, dan bukan digunakan untuk kepentingan grup pemilik bank. ${ }^{3}$

Berdasarkan paparan di atas menunjukkan, bahwa berbagai kebijakan tersebut telah mendorong bagi timbulnya kejahatan ekonomi di bidang perbankan.yang dilakukan oleh bank (korporasi) dan sekaligus juga telah memunculkan adanya korban. Di samping itu, dengan adanya kejahatan yang dilakukan oleh korporasi (bank sebagai pelaku kejahatan), menunjukkan telah terjadi perkembangan mengenai pelaku kejahatan ekonomi di bidang perbankan dan korbannya. Jika semula hanya bank yang dianggap sebagai sasaran atau target pelaku kejahatan, dalam perkembangannya, bank pun dapat melakukan kejahatan atau sebagai pelaku kejahatan ekonomi di bidang perbankan.

Sesuai dẹngan judul yang telah diajukan di atas, maka mengkaji perlindungan terhadap korban kejahatan ekonomi di bidang perbankan, merupakan suatu hal yang sangat urgen dalam sistem hukum pidana nasional. Mengingat dalam penyelenggaraan perekonomian di suatu negara, termasuk Indonesia, bank memiliki peranan yang strategis sebagai penggerak roda perekonomian, baik dári segi pelaksanaan kebijakan moneter, sistem pembayaran, pengerahan dana maupun penyaluran kredit kepada masyarakat. Lembaga perbankan mempunyai posisi sentral dalam pembangunan nasional, mempunyai predikat sebagai lembaga kepercayaan.

Dengan demikian sudah dapat diperkirakan, lemahnya dunia perbankan akan berpengaruh terhadap perekonomian nasional. Oleh karena bank memiliki peranan yang strategis sebagai

${ }^{2}$ Listyorini, "Menyoal Fungsi BI sebagai Lender of the Last Resort", harian Suara Pembaruand Dalam "Bank Indonesia, Bantuan Likuiditas Bank Indonesia (BLBI)", http://mww.bi.go.jd/bank indonesia2/spesial/bibi/

${ }^{3}$ Siaran Pers BPK tentang Hasil Audit Investigasi atas Penyaluran dan Penggunaan BLBI, dalam "Bank Indonesia, Bantuan Likuiditas Bank Indonesia (BLBI)", http://www.bi.go.jdbank indonesia2/spesial/hlbi// 
penggerak roda perekonomian, sedangkan tumbuh dan berkembangnya bank sangat tergantung pada sampai sejauh mana masyarakat menaruh kepercayaannya kepada bank yang akan mengelola dananya yang dipercayakan disimpan di bank. Ini berarti, trust (kepencayaan) dari para pengguna jasa perbankan atau pun nasabah, dan lain-lainnya itu merupakan modal utama yang harus dipegang teguh oleh bank.

Mengingat korban akibat kejahatan yang dilakukan oleh bank (korporasi) cukup besar, maka sudah seharusnya meridapatkan perlindungan dalam hukum pidana. Para korban dimaksud antara lain: nasabah, baik individual maupun kolektif (perusahaan), dan masyarakat atau negara.

\section{Konsepsional}

Orientasi perlindungan korban kejahatan ekonomi di bidang perbankan, ditujukan - terhadap potential victim maupun actual victim. Karena itu, seperti yang ditulis oleh Barda Nawawi Arief ${ }^{4}$ bahwa konsep pemidaan harus bertolak dari keseimbangan antara dua sasaran pokok, yaitu perlindungan masyarakat dan perlindungan individu. Perlindungan individu ini menurut hemat penulis harus pula diperluas untuk diarahkan pada perlindungan terhadap actual victim.

Dengan konsep yang demikian, maka untuk hukum pidana yang akan datang seyogyanya mengimplementasikan perlindungan yang seimbang antara perlindungan masyarakàt, pelakku, dan korban (korban langsung). Ini merupakan konsep yang ideal dalam rangka membangun hukum pidana yang lebih bijak karena memperhatikan berbagai kepentingan tersebut.

Oleh karena itu, untuk memberikan perlindungan terhadap korban sejak awal dalam menentukan kebijakan ekonomi di bidang perbankan para pengabil kebijakan sudah seharusnya memperhatikan bidang hukum (pidana). Menurut Sheryl W. Gray adalah keliu apabila pembaharuan di bidang ekonomi dianggap terpisah dengan pembaharuan di bidang hukum. Karena sebagian besar . kebijakan ekonomi diwujudkan pelaksanaannya melalui hukum, dan di sisi lain analisa-analisa ekonomi akan dipakai sebagai panduan oleh para pembuat kebijakan ketika harus merancang hukum.

Menurut Sudarto ${ }^{6}$ jika hendak melibatkan pendekatan politik hukum pidana (dalam rangka melindungi korban kejahatan ekonomi di bidang perbankan, pen.) harus dilihat dalam hubungan keseluruhan politik kriminal. Ini pun harus merupakan bagian integral dari rencana pembangunan nasional. Keterkaitan tersebut dapat diperlihatkan skema berikut ini:?

${ }^{4}$ Barna Nawawi Arief, Bunga Rampai Kebijakan Hukum Pidana (Bandung: Citra Aditya Bakti, 1996), him 98.

5 "Membangun Hukum yang Pro Pasar", Jumal Hukum Bisnis, Volume 6 Tahun 1999, hlm 30.

'Sudarto, Hukum dan Hukum Pidana (Bandung: Alumni, 1983), hilm 104.

${ }^{7}$ Barda Nawawi Arief, op.cit., hlm 3. 


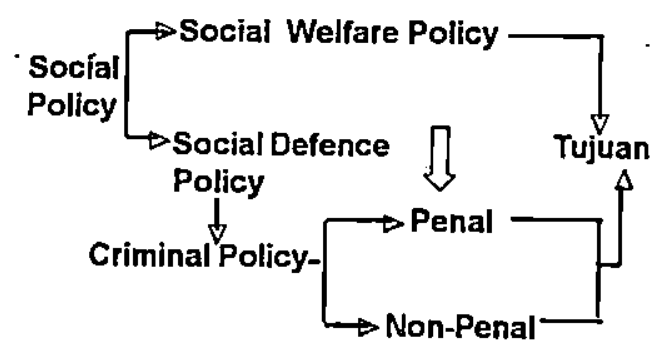

Politik Hukum Pidana dan Kejahatan Ekonomi di bidang Perbankan

\section{Ruang Lingkup Politik Hukum Pidana}

Politik hukum pidana (dalam tataran mikro), merupakan bagian dari politik hukum (dalam tataran makro), karena itu dalam bidang hukum pidana melaksanakan politik hukum pidana, berarti usaha mewujudkan peraturan perundang-undangan pidana yang sesuai dengan keadaan dan situasi pada suatu waktu dan untuk masa-masa yang akan datang. ${ }^{8}$

Sekarang yang menjadi pertanyaan, bagaimanakah implementasi politik hukum pidana (kebijakan penal) dalam rangka perlindungan korban kejahatan ekonomi di bidang perbankan. Apabila hukum pidana hendak dilibalkan, maka harus dilihat dalam hubungan keseluruhan politik kriminal.

Dengan demikian, jika politik kriminal dengan menggunakan politik hukum pidana, maka harus merupakan langkah-langkah yarig dibuat dengan sengaja dan sadar. Memilih dan menetapkan hukum pidana sebagai sarana untuk menanggulangi kejahatan harus benarbenar telah memperhitungkan semua faktor yang dapat mendukung berfungsinya atau bekerjanya hukum pidana dalam kenyataannya. ${ }^{9}$ Oleh karena itu, maka proses kriminalisasi yang terus berlangsung harus dilakukan evaluasi.

Dengan mengevaluasi berbagai kebijakan yang telah dituangkan dalam proses kriminalisasi, maka pemikiran-pemikiran yang hendak mengedepankan hukum pidana sebagai salah satu instrumen bagi perlindungan korban kejahatan ekonomni di bidang perbankan dapat dipertimbangkan, karena mengingat kelihaian pelaku yang terkadang sulit terdeteksi oleh aparat penegak hukum, bahkan sarana perdata atau tindakan administrasi belum mampu membendung para polaku kejahatan krah putih (white-collar criminal) itu beraksi. Akibatnya, perlindungan terhadap korban dirasakan masih belum memadai.

Mengkaji perlindungan korban kejahatan ekonomi di bidang perbankan dengan menggunakan sarana hukum pidana, perlu terlebih dahulu disinkronkan dengan isu sentral dalam hukum pidana. Mengenai hal ini, Barda Nawawi Arief menyatakan ${ }^{10}$ bahwa masalah pokok dalam hukum pidana meliputi: masalah tindak pidana; masalah kesalahan atau pertanggungjawaban pidana; dan masalah pidana dan pemidanaan. Di samping itu, Packer menyatakan" bahwa dasar rasional

\footnotetext{
${ }^{8}$ Sudarto, Hukum Pidana dan Perkembangan Masyarakat: kajian terhadap pembaharuan hukum pidana (Bandung: Sinar Baru, 1983), him 93-94.

${ }^{9}$ Barda Nawawi Arief, op.cit., hlm 37.

${ }^{10}$ Barda Nawawi Arief, op.cit., hlm 87.

"HerbertL. Packer, The Limits of the Criminal Sanction (California: Stanford University Press, 1968), hlm 17. The rationale of the criminal law rests on three concepts: offense; guilt; and punishment.
} 
dari hukum pidana bersandar pada tiga konsep, yaitu: tindak pidana, kesalahan, dan pemidanaan.

Ketiga pilar tersebut, merupakan dasar atau titik-tolak untuk mengkaji tentang politik (kebijakan) hukum pidana dalam rangka perlindungan korban kejahatan ekonomi di bidang perbankan, yaitu korban akibat dari kejahatan yang dilakukan oleh korporasi, dalam hal ini bank sebagai korporasi. Dengan demikian, ruang lingkup kebijakan perlindungan korban yang akan dikaji meliputi: perbuatan pidana; sistem pertanggungjawaban pidana korporasi; dan pidana dan pemidanaan.

\section{Ruang Lingkup Kejahatan Ekonomi di Bidang Perbankan}

Sahetapy menyatakan ${ }^{12}$ bahwa pengertian atau makna kejahatan bisa saja tumpang tindih dengan pengertian kejahatan secara yuridis, atau bisa juga serupa dengan makna kejahatan secara kriminologis. Namun yang jelas menurut Sahetapy makna dan ruang lingkup kejahatan secara yuridis tidak sama dan tidak serupa dengan makna serta ruang lingkup makna kejahatan secara kriminologis.

Dengan demikian, ada perbedaan pendapat dalam melihat kejahatan sebagai gejala masyarakat. Dalam kaitan ini, Sudarto mengemukakan: ${ }^{13}$

orang tidak akan berbeda pendapat, bahwa penodongan itu suatu kejahatan, akan tetapi mengenai permintaan "uang hangus" oleh seorang pegawai bank yang terpaksa harus dituruti oleh seorang peminjam uang, yang disinyalir oleh Presiden Suharto sebagai hal yang harus dihapus, mungkin ada orang yang berpendapat, bahwa itu sesuatu yang sudah sewajarnya!

Pertanyaannya: apakah dalam kasus penyalahgunaan BLBI yang dilakukan oleh bank (korporasi) masih disepakati perbuatan tersebut bukan merupakan kejahatan? Jawaban untuk pertanyaan ini, barangkali dapat dikembalikan pada pendapat Sahetapy di atas tadi, yang pada akhirnya bergantung dari sudut mana orang hendak melihatnya, apakah dari sudut yuridis ataukah dari sudut kriminologis. Apabila hendak dilihat dari sudut yuridis, pertanyaannya: apakah kejahatan berupa penyalahgunaan dana BLBI tersebut merupakan kejahatan menurut hukum pidana positif. Jika demikian halnya, tentu tidak ada pilihan lain, kecuali membuka undang-undang. Sebaliknya, apabila hendak melihat dari sudut kriminologis, jawabannya pun tergantung pada siapa yang melihatnya, dan itu juga tergantung dari subyektivitas dan yang terancam kepentingannya.

Kejahatan ekonomi di bidang perbankan yang merupakan salah satu bentuk kejahatan ekonomi yang terdiri dari kejahatan di bidang perdagangan, kejahatan di bidang investasi, kejahatan di bidang perusahaan, kejahatan di bidang lingkungan hidup, asuransi, pajak, maritim, dan kejahatan-kejahatan di bidang ekonomi lainnya. Karena itu, dapat dikategorikan sebagai bagian dari kejahatan ekonomi dalam arti luas.

Di samping ruang lingkup kejahatan ekonomi di bidang perbankan tersebut merupakan bagian dari kejahatan ekonomi dalam arti luas, juga apabila dikaitkan dengan bank (korporasi sebagai subjek), maka dalam

12. J.E. Sahetapy, Teori Kriminologi Suatu Pengantar (Bandung: Citra Aditya Bakti, 1992), him 67.

${ }^{13}$ Sudarto, op.cit., hlm 161. 
konteks kejahatan ekonomi di bidang perbankan ini meliputi: (1) bank sebagai sarana untuk melakukan kejahatan; (2) bank sebagai sasaran untuk melakukan kejahatan; dan (3) bank sebagai pelaku kejahatan.

Memfokuskan kajian pada bank sebagai pelaku kejahatan, adalah sesuai dengan perkembangannya, terlebih setelah dikeluarkannya kebijakan paket Deregulasi 27 Oktober 1988, ternyata bank juga dapat menjadi pelaku kejahatan ekonomi di bidang perbankan. Ini berarti, berbicara mengenai pelaku dalam lingkup kejahatan ekonomi di bidang perbankan, jika semula yang dianggap sebagai pelaku hanyalah individu atau sejumlah individu atau perusahaan, dalam perkembangannya terjadi pergeseran, di mana bank juga dapat menjadi pelaku kejahatan.

\section{Dampak Kejahatan Ekonomi di Bidang Perbankan dan Korban yang Ditimbulkan}

Kejahatan ekonomi di bidang perbankan, sebagai salah satu bentuk kejahatan ekonomi dengan tanpa menggunakan kekerasan, namun dampaknya jauh lebih besar dibandingkan dengan kejahatan konvensional. Pelakunyapun berkembang, semula yang dapat melakukan kejahatan hanyalah manusia, namun dengan adanya temuan dari ilmu hukum (normatif), korporasi diakui sebagai subjek hukum pidana (kecuali dalam Undang-undang tentang Pérbankan).

Pengertian kejahatan korporasi, sebenarnya merupakan bagian dari white-collar crime, Clinard dan Yeager menulis, ${ }^{14}$ white-collar crime terdiri dari dua bagian, yaitu occupational crime dan corporate crime. Mengenai occupational crime tidak diuraikan lebih lanjut dalam tulisan ini, karena yang dipokuskan adalah pada corporate crime. Menurut Shapiro kejahatan korporasi adalah kejahatan yang dilakukan oleh kolektif atau kumpulan individu dengan bidang (pekerjaan) yang berbeda. Pada intinya, untuk dapat disebut sebagai kejahatan korporasi, jika pejabat atau pengurus korporasi melakukan pelanggaran hukum untuk kepentingan korporasi. ${ }^{15}$

Meskipun kejahatan korporasi sudah melanda ke berbagai penjuru dunia, akan tetapi sebagaimana yang ditulis oleh Clinard ${ }^{16}$ bahwa berdasarkan survey nasional yang dilakukan pada tahun 1978 menunjukkan adanya perubahan persepsi masyarakat Amerika Serikat dalam memandang kejahatan korporasi itu sebagai kejahatan yang serius (kejahatan yang sangat merugikan) dibandingkan dengan kejahatan biasa seperti pencurian dan perampokan. Bahkan, dalam tahun 1980-an tingkat pencelaan masyarakat terhadap kejahatan korporási lebih hebat lagi dibandingkan dengan hasil survey tahun 1978 tersebut.

Salah satu dari mereka yang dipandang merugikan negara, adalah keterlibatan korporasi menyumbang dana politik secara illegal, seperti misalnya antara lain pendanaan untuk kampanye pemilihan presiden. Menurut Clinard dan Yeage ${ }^{17}$ sumbangan tersebut pada umumnya untuk tujuan ekonomi, yaitu untuk menikmati jaminan birokrasi dan

\footnotetext{
${ }^{14}$ Marshall| B. Clinard and Peter C. Yeager, Corporate Crime (New York: The Free Press, 1980), hlm 18.

${ }^{15} \mathrm{lbid}$.

${ }^{16} \mathrm{lbid}$., hlm 16.

${ }^{17} \mathrm{Ibid}$, him 157.
} 
mempengaruhi politik, sehingga akan berpengaruh pada peningkatan keuntungan korporasi yang lebih besar lagi.

Demikian juga dengan sumbangan seperti yang dilakukan oleh salah seorang konglomerat Indonesia, James Riady dari Lippo Group, menyumbang dana sebesar US $\$ 175.000$ untuk kepentingan kampanye Bill Clinton yang saat itu bersaing dengan Bob Dole dari partai Republik. Karena itu, pada tanggal 11 Oktober 1996, Senator John McCain meminta Departemen Kehakiman mengusut kasus itu. ${ }^{18}$

Berbagai bentuk kejahatan korporasi lainnya yang melibatkan bank sebagai pelaku kejahatan ekonomi di bidang perbankan, adalah kasus Bank Summa. Dana yang dihimpun dari masyarakat seharusnya disalurkan sesuai ketentuan yang berlaku, yaitu kembali kepada masyarakat lagi. Akan tetapi, dana tersebut lebih banyak disalurkan kepada perusahaan yang satu group dengannya. Karena itu, ketentuan mengenai kelayakan jaminan sebagai syarat untuk memperoleh kredit, tidak dilakukan sebagaimana mestinya. ${ }^{19}$

Sebagaimana yang dipaparkan oleh Center for Banking Crisis ${ }^{20}$ bahwa kejahatan ekonomi di bidang perbankan, meliputi pula antara lain penyalahgunaan dana BLBl, pelanggaran BMPK, manipulasi data laporan. Mengenai penyalahgunaan dana BLBI ini, Panja BLBI Komisi IX DPR-Rl pada tanggal 6
Maret 2000 dalam laporannya menyatakan, ${ }^{21}$ bahwa sebelum krisis moneter pertengahan Juli 1997, bahkan sejak tahun 1995 sudah terdapat beberapa bank yang mengalami saldo debet yang berkepanjangan dan terus mendapat fasilitas bantuan likuiditas dari Bank Indonesia tanpa pernah mengalami skors kliring. Bank-bank tersebut antara lain Bank Artha Prima, Bank Industri, South East Asia Bank Ltd., Bank Pinaesan.

Menurut BPK, pelanggaran yang paling umum, adalah rekaya transaksi untuk menghindari BMPK dengan cara $\mathrm{a}^{22}$ seperti membuat perusahaan-perusahaan fiktif yang seolaholah perusahaan tersebut bukan grupnya. Padahal kesemua itu hanya paper company, bahkan alamatnyapun palsu. ${ }^{23}$

Pertanyaannya: apakah timbulnya krisis disebabkan oleh pengelolaan bank yang kurang professional, berupa kejahatan yang dilakukan bank yang berakibat pada hancurnya perbankan itu sendiri. Atau hancurnya perbankan memang disebabkan oleh krisis moneter? Mengacu pada Laporan Panja BLBI Komisi IX DPR-RI di atas, krisis moneter itu terjadinya pada pertengahan Juli 1997, sedangkan praktek perbankan yang buruk sudah berlangsung sebelum 1997. Dengan demikian, hancurnya lembaga perbankan bukan disebabkan oleh krisis moneter, melainkan praktek perbankan yang buruk itulah yang justru menciptakan krisis moneter.

18 Jawa Pos, 15 Oktober 1996, hlm 1.

${ }^{19}$ Majalah Forum Keadilan, No. 19, 7 Januari 1993, hlm 85.

${ }^{20}$ Center for Banking Crisis, Buku Puth, Jilid I, (Jakarta: 1999), hlm 10-13.

${ }^{21}$ Bank Indonesia, "Bantuan Likuiditas Bank Indonesia (BLBI)", Lampiran 9, Petikan Laporan Panja Komisi IXDPR-RI tanggal 6 Maret 2000. http:/hwwwbi.go.id/bank indonesia2/spesial/b/bi/BLBl-utama.htm.

${ }^{22} \mathrm{lbid}$.

${ }^{23}$ Center for Banking Crisis, op. cit., him 11. 
Dalam hubungan ini Tulus Tambunan menulis ${ }^{24}$ bahwa hubungan antara kondisi perbankan dengan krisis moneter bagaikan hubungan antara dua variable yang tidak berdiri sendiri, dan saling mempengaruhi satu sama lain. Menurut Tambunan, struktur perbankan yang lemah dapat memperburuk krisis moneter. Untuk argumen itu, Tambunan memberikan gambaran, salah satu penyebab krisis ekonomi yang diawali oleh krisis mata uang di Asia, salah satunya disebabkan oleh kondisi sistem perbankan yang buruk di kawasan tersebut. Selain itu, seperti yang ditulis oleh Smith ${ }^{25}$ bahwa:

before the crisis of the 1930s, banking system had been funneling the nation's money towards large money centers where it was used for speculation and not production. As this destroyed the public's buying power, this was a prime cause of the Great Depression.

Dengan demikian, pengalaman krisis ekonomi yang melanda dunia pada 1930-an, faktor penyebabnya bermula dari pengelolaan sistem perbankan yang kurang baik. Karena itu menurut Tambunan ${ }^{26}$ kondisi perbankan menjadi semakin buruk dengan munculnya . krisis rupiah pada pertengahan tahun 1997.

Ini berarti, terjadinya krisis yang berkepanjangan di Indonesia, serta berkurangnya kepercayaan masyarakat terhadap lembaga perbankan, yang mengakibatkan pula hancurnya lembaga perbankan, merupakan dampak dari kejahatan ekonomi di bidang perbankan yang dilakukan oleh bank. Dampak berikutnya, adalah timbulnya korban yang jauh lebih besar dibandingkan dengan korban kejahatan biasa (konvensional). Oleh karena itu, perlu dikaji langkah-langkah atau kebijakan dalam rangka perlindungan korban kejahatah ekonomi di bidang perbankan.

\section{Perlindungan Korban Kejahatan Ekonomi di Bidang Perbankan}

\section{Dalam Hukum Pidana Positif}

Undang-undang Perbankan dapat digolongkan dalam peraturan perundangundangan di bidang hukum administratif yang memuat sanksi pidana. Menurut Reksodiputro ${ }^{27}$ peraturan semacam ini harus dibedakan dengan UUTPE dan Undang-undang tentang Pemberantasan Tindak Pidana Korupsi, Undang-undang No. 31 Tahun 1999 sebagaimana diubah dengan Undang-undang No. 20 Tahun 2001. Jika kedua undang-undang ini dapat dikatakan adanya tindak pidana ekonomi dan tindak pidana korupsi, maka untuk Undang-undang tentang Perbankan, Reksodiputro mempertanyakan: dapatkah dikatakan adanya kejahatan perbankan? Untuk menjawab pertanyaan ini, Reksodiputro mengutip tulisan Anwar yang mencoba mengintrodusir

${ }^{24}$ Tulus Tambunan, Krisis Ekonomi dan Masa Depan Reformasi, (Jakarta: Lembaga Penerbit Fakultas Ekonomi Universitas Indonesia, 1998), him 202.

${ }^{25} \mathrm{~J}$. W. Smith, The World's Wasted Wealth, The Political Economy of Waste (Kalispell, Montana: New Worlds Press; 1989), hlm 206.

${ }^{26}$ Tulus Tambunan, op.cit., hlm 203.

${ }^{27}$ Mardjono Reksodiputro, op.cit., hlm 327-328. 
istilah tindak pidana-di bidang perbankan sebagai upaya untuk menampung segalajenis perbuatan melanggar hukum yang berhubungan dengan kegiatan-kegiatan dalam menjalankan usaha bank. Maksud mengintrodusir pengertian ini, karena belum ada peraturan-peraturan hukum pidana yang secara khusus dibuat untuk mengancam dan menghukum perbuatanperbuatan yang berkaitan dengan pelanggaran terhadap ketentuan dalam menjalankan usaha bank.

Berdasarkan uraian di atas, meskipun . berbagai kejahatan tersebut dapat dilakukan oleh korporasi (bank). Akan tetapi, karena dalam KUHP korporasi bukan merupakan subjek hukum pidana, maka sudah barang tentu korporasi tidak dapat dipertanggungjawabkan secara pidana. Apalagi jika bank dijadikan sebagai sasaran kejahatan, maka bukan lagi berbicara tentang kejahatan korporasi, melainkan lebih mengarah pada kejahatan white-collar. Dengan konstruksi demikian, berarti secara normatif tidak ada korban kejahatan ekonomi di bidang perbankan, dalam arti bank sebagai korporasi melakukan kejahatan yang dapat menimbulkan korban.

Berikutnya, bagaimana dengan produk hukum di erakemerdekaan. Apakah perlindungan korban, termasuk korban kejahatan ekonomi di bidang perbankan sudah diatur dalam undangundang tersebut. Undang-undang No. 31 Tahun 1999 sebagaimana diubah dengan Undangundang No. 20 Tahun 2001, mengatur korporasi sebagai subjek hukum pidana, sehingga tidak diragukan lagi korporasi dianggap dapat melakukan tindak pidana korupsi.

Kaitannya dengan Undang-undang No. 7 Tahun 1992 sebagaimana diubah dengan Undang-undang No. 10 Tahun 1998, apakah dalam Undang-undang ini adaketentuan yang menyebutkan bahwa korporasi dapat dipidana berdasarkan Undang-undang No. 31 Tahun 1999 sebagaimana dirubah dengan Undangundang No. 20 Tahun 2001? Pertanyaan ini mengemuka, karena adanya ketentuan Pasal 14 dalam Undang-undang ini yang menyatakan: setiap orang yang melanggar ketentuan Undang-undang yang secara tegas menyatakan bahwa pelanggaran terhadap ketentuan Undang-undang tersebut sebagai tindak pidana korupsi berlaku ketentuan yang diatur dalam Undang-undang.ini. Dalam Undang-undang No. 7 Tahun 1992 sebagaimana diubah dengan Undang-undang No. 10 Tahun 1998, tidak ada ketentuan yang menyatakan bahwa korporasi dapat dituntut berdasarkan Undang-undang $\mathrm{No}$. 31 Tahun 1999 sebagaimana diubah dengan Undang-undang No. 20 Tahun 2001, terlebih dalam Undang-undang No. 7 Tahun 1992 sebagaimana telah diubah dengan Undangundang No. 10 Tahun 1998 tidak mengatur korporasi sebagai subjek hukum pidana.

Dengan demikian, meskipun dalam Undang-undang No. 31 Tahun 1999 sebagaimana dirubah dengan Undang-undang No. 20 Tahun 2001, korporasi merupakan subjek hukum yang dapat dijatuhi pidana, akan tetapi pada tataran penegakannya ternyata masih sulit diwujudkan. Hal ini sesuai dengan catatan Mardjono Reksodiputro yang disampaikan kepada penulis pada saat ujian Proposal Program Doktor IImu Hukum pada Program Pascasarjana Universitas Airlangga tanggal 23 Pebruari 2001, bahwa dalam praktek penerapan hukum pidana terhadap korporasi, misalnya dalam kasus pelanggaran BMPK dan penyalahgunaan BLBI sukar dibuktikan dan sulit pula dialihkan kepada direksi sebagai pemikul tanggung jawab. Permasalahan pada tahap operasionalisasi ini, akan berakibat 
pada lemahnya perlindungan terhadap korban. Di samping itu, pada tataran regulasi, khususnya terhadap korban riel, memang tidak ada ketentuan yang secara tegas mengatur perlindungan secara konkrit ațau langsung kepada korban.

\section{Dalam Hukum Pidana yang akan Datang}

Ruang lingkup perlindungan korban dalam tulisan ini bertumpu pada: perbuatan pidana; pertanggungjawaban pidana korporasi; pidana dan pemidanaan. Mendiskusikan perbuatan pidana sebagai salah satu pilar dalam hukum pidana, maka yang perlu ditelusuri: perbuatanperbuatan apa sajakah yang belum diatur dalam Undang-undang No. 7 Tahun 1992 sebagaimana diubah dengan Undang-undang No. 10 Tahun 1998.

Terdapat beberapa kejahatan yang belum diatur dalam Undang-undang No. 7 Tahun 1992 sebagaimana diubah dengan Undangundang No. 10 Tahun 1998, yaitu: 1). Kejahatan yang menyangkut pemberian informasi tidak benar kepada masyarakat atau calon nasabah. 2) Kejahatan yang menyangkut praktek bank dalam bank. 3) yang menyangkut pelanggaran ketentuan mengenai Batas Maksimum Pemberian Kredit (BMPK). 4) perbuatanperbuatan yang mengandung unsur tindak pidana korupsi.

Oleh karena itu, baik yang menyangkut kejahatan fraudulent misrepresentation maupun bentuk kejahatan lainnya, maka peninjauan kembali Undang-undang No. 7 Tahun 1992 sebagaimana dirubah dengan Undang-undang No. 10 Tahun 1998 adalah relevan guna perbaikan hukum pidana yang akan datang, sehingga kepentingan korban dapat dilindungi. Demikian juga yang menyangkut pertanggungjawaban pidana korporasi, serta pidana yang akan dikenakan kepada korporasi.

Untuk mempertanggungjawabkan pidana korporasi (corporate criminal responsibility), terlebih dahulu perlu mengacu kepada doktrin dasar dalam hukum pidana. Menurut Barda Nawawi Arief ${ }^{28}$ dalam hukum pidana pada umumnya yang dapat dipertanggungjawabkan adalah pelaku, yaitu orang yang telah melakukan tindak pidana tertentu, akan tetapi tidak selalu demikian, karena masih bergantung pada perumusan yang dilakukan oleh pembuat undang-undang. Di samping itu, Moeljatno menulis $^{29}$ bahwa meskipun orang telah melakukan tindak pidana, akan tetapi si pelaku belum tentu dapat dipidana sebagaimana yang diancamkan dalam hukum pidana, karena masih bergantung: apakah dalam melakukan tindak pidana itu dia mempunyai kesalahan.

Persoalannya, apakah dalam hal pertanggungjawaban pidana korporasi, masih relevan mengkaitkan dengan doktrin tentang pandangan dualistik dalam hukum pidana, yang memisahkan antara perbuatan dan kesalahan. Di negara-negara Anglo Saxon, perkecualian untuk tidak mencantumkan unsur kesalahan dalam mempertanggungjawabkan pelaku kejahatan, termasuk korporasi adalah menggunakan doktrin strict liability dan vicari-

${ }^{28}$ Barda Nawawi Arief, "Masalah Pemidanaan Sehubungan dengan Perkembangan Delik Khusus dalam Masyarakat Modem", dalam Muladi dan Barda Nawawi Arief, Teori-teori dan Kebijakan Pidana (Bandung: Alumni, 1984), hlm 136.

${ }^{29}$ Moeljatno, Asas-asas Hukum Pidana (Yogyakarta: UGM Press, 19800), hlm 104. 
ous liability. Menurut Gillies ${ }^{30}$ pertanggungjawaban pidana dikatakan menjadi strict apabila perbuatan yang telah dilakukan tidak lagi memperhatikan adanya kesalahan seseorang. Karena itu, seseorang dapat dipertanggungjawabkan, meskipun yang bersangkutan tidak melakukan kesalahan, yaitu seperti adanya unsur kesengajaan (consisting in intention). Lebih lanjut Gillies menulis bahwa konsep strict liability tersebut disusun sebagai perkecualian terhadap asas common law. Karena, berdasarkan doktrin common law suatu kejahatan mensyaratkan adanya mens rea di hampir semua kasus sebagai dasar untuk menjatuhkan pidana (criminal liability).

Selanjutnya, mengenai vicarious liability, Gillies menulis ${ }^{31}$ bahwa vicarious liability dalam hukum pidana dapat digambarkan sebagai pengenaan pertanggungjawaban pidana kepada seseorang dalam kapasitas pelaku utama, berdasarkan atas perbuatan pelanggaran atau sekurang-kurangnya ada unsur pelanggaran yang dilakukan oleh orang lain. Contoh dari bentuk pertanggungjawaban ini, adalah hubungan antara karyawan dan pimpinan (employer-employee situation). Atau dengan kata lain, vicarious liability berarti pertanggungjawaban atas perbuatan yang dilakukan oleh orang lain (liability for the acts of another person) $)^{32}$

Berdasarkan kedua doktrin pertanggungjawaban pidana di atas, maka bagaimana dengan hukum pidana kita yang akan datang? Apakah sudah berorientasi pada bentuk pertanggungjawaban pidana seperti ini?
Dalam RUU tentang KUHP tahun 1999-2000, Pasal 32 ayat (2) dan (3) masing-masing berbunyi: Pasal 32 ayat (2): Dalam hal tertentu, seseorang dapat dipertanggungjawabkan atas tindak pidana yang dilakukan oleh orang lain, jika ditentukan dalam suatu undang-undang. Ketentuan yang tercantum dalam Pasal 32 ayat (2) ini, merupakan permjudan atau implementasi dari diadopsinya asas vicarious liability sebagaimana yang dianut oleh negara-negara yang berdasarkan pada common law.

Dengan diadopsinya kedua doktrin pertanggungjawaban pidana tersebut, maka apabila dikaitkan dengan pertanggungjawaban pidana korporasi, dalam hal ini adalah bank, akan besar sekali pengaruhnya dalam upaya penanggulangan kejahatan ekonomi di bidang perbankan dengan menggunakan sarana hukum pidana (penal). Dengan demikian sekaligus akan menciptakan adanya perlindungan korban kejahatan ekonomi di bidang perbankan. Namun masalahnya sekarang, Undang-undang tentang Perbankan yang diatur dalam Undang-undang No. 7 Tahun 1992 sebagaimana dirubah dengan Undang-undang №. 10 Tahun 1998, ketentuan pidananya masih belum berorientasi kepada kedua doktrin pertanggungjawaban pidana yang telah diadopsi oleh RUU tentang KUHP tersebut. Apabila nantinya RUU tentang KUHP sudah diundangkan sebagai hukum pidana positif, maka ketentuan pidana di luar KUHP perlu disesuaikan dengan ketentuan KUHP, sehingga akan terjadi kesesuaian dengan Pasal 32 ayat (2) RUUtentang KUHP Tahun 1999-2000.

30. Peter Gillies, Criminal Law, Second Edition (Sydney. The LawBook Company Limited, 1990), hlm 78-79.

${ }^{31}$ Peter Gillies, ibid., hlm 107.

${ }_{32}$ Russel Heaton, Criminal Law, Cașes \& Naterials, Second Edition (London: Blackstone Press Limited, 1998), hlm 404. 
Berdasarkan uraian di atas, berarti untuk hukum pidana yang akan datang, permasalahan korporasi sebagai subjek hukum pidana sudah tidak dipersoalkan lagi, demikian juga dengan pertanggungjawaban pidananya, terlebih lagi dengan diadopsinya doktrin strict liability dan vicarious liability yang selama ini hanya dianut oleh negara-negara Anglo Saxon.

Namun, berikutnya yang menjadi permasalahan, pidana apakah yang paling tepat dikenakan terhadap korporasi. Dalam arti, pidana yang akan dikenakan itu harus diorientasikan kepada perlindungan korban, baik terhadap calon korban maupun terhadap korban secara langsung. Jadi, bank sebagai korporasi yang telah melakukan kejahatan ekonomi tersebut, harus bertanggung jawab secara pidana atas perbuatan yang telah berakibat pada timbulnya korban.

Sehubungan dengan itu, Muladi menulis ${ }^{33}$ bahwa hukum pidana sebagai bagian dari sistem yang lebih luas tidak dapat menghindarkan diri dari berbagai perkembangan yang terjadi dalam sistemyang lebih besar, di antaranya adalah sistem ekonomi. Menurut Muladi, keterlibatan hukum pidana selain dapat bersifat otonom, juga dapat bersifat sebagai pelengkap terhadap hukum lain, misalnya hukum administrasi.

Dikaitkan dengan Undang-undang No. 7 Tahun 1992 sebagaimana diubah dengan Undang-undang No. 10 Tahun 1998, yang merupakan perundang-undangan administrasi yang bersanksi pidana, makakedudukan hukum pidana menurut Muladi ${ }^{34}$ adalah sebagai penunjang penegakan norma yang berada dalam hukum administrasi tersebut. Kendati kedudukannya sebagai penunjang, akan tetapi dalam hal-hal tertentu lanjut Muladi, hukum pidana dapat juga lebih fungsional daripada sekedar hanya berfungsi subsidiair. Alasannya, karena mengingat kepentingan hukum yang dilindungi sangat besar, yakni sistem ekonomi suatu bangsa (miring tebal, pen.). Meskipun begitu, Muladi mengingatkan bahwa penggunaan hukum pidana sebagai primum remedium harus dilakukan dengan hati-hati dan selektif, yaitu dengan mempertimbangkan, baik kondisi objektif (yang berkaitan dengan perbuatan) maupun hal-hal subjektif (yang berkaitan dengan pelaku), kerugian yang ditimbulkan, kesan masyarakat terhadap tindak pidana yang bersangkutan, serta tujuan pemidanaan yang hendak dicapai.

Sesuai dengan konteks pembahasan mengenai politik hukum pidana terhadap perlindungan korban kejahatan ekonomi di bidang perbankan, maka penggunaan hukum pidana sebagai salah satu sarana untuk melindungi berbagai kepentingan yang telah disugikan akibat kejahatạn yang dilakukan oleh korporasi, pada prinsipnya tetap berpijak pada asas ultimum remedium, akan tetapi dalam hal-hal tertentu sudah saatnya dipertimbangkan penggunaan hukum pidana sebagai primum remedium.

${ }^{33}$ Muladi, "Proyeksi Hukum Pidana Materiil Indonesia di masa Datang", Pidato Pengukuhan Jabatan Guni Besar dalam bidang IImu Hukum (Semarang: Fakultas Hukum Universitas Diponegoro, 24 Pebruari
1990), hlm 6-7.

${ }^{34} \mathrm{Ibid.,} \mathrm{him} \mathrm{7-8.}$ 
Dalam pada itu, Harry V. Ball dan Lawrence M. Friedman menulis ${ }^{35}$ bahwa apabila berbicara mengenai penggunaan sanksi pidana, pikiran kita akan tertuju pada lebih dari satu arti istilah yang digunakan, yaitu seperti perbedaan antara: (a) penetapan sanksi pidana oleh pembentuk undang-undang; dan (b) penerapannya oleh aparat penegak hukum. Pada pengertian yang pertama, hukum dapat dikatakan menggunakan sanksi apabila pembentuk undang-undang yang . menggunakannya. Sedangkan pada pengertian yang kedua, sanksi digunakan apabila secara nyata diterapkan. Selanjutnya, apa yang kita maksudkan dengan istilah sanksi pidana itu? Undang-undang yang ditujukan pada peraturan ekonomi sering menyediakan berbagai alternatif sanksi, yaitu seperti ganti kerugian, denda yang bernilai uang, perampasan barangbarang, pencabutan izin usaha, pidana penjara, pidana bersyarat dengan ancaman denda atau penjara jika pidana bersyarat itu dilanggar. Kesemua sanksi tersebut, umumnya dianggap sebagai sanksi pidana.

Sehubungan dengan bermacam jenis sanksi tersebut, bagaimanapun juga sanksi denda atau penebusan dengan uang, sudah digunakan secara luas sebagai sanksi. Karena itu menurut Harry V. Ball dan Lawrence M. Friedman, ${ }^{36}$ mempertanyakan apakah sanksi yang bernilai uang atau denda itu merupakan sanksi yang tepat dikenakan terhadap organisasi bisnis (business organization), merupakan pertanyaan yang tidak relevani lagi untuk diperdebatkan, apalagi dengan menanyakah apakah sanksi pidana denda termasuk dalam lingkup hukum perdata ataukah hukum pidana.

Kaitannya dengan pidana denda tersebut, para ahli kriminologi sebagaimana ditulis oleh Harry V. Ball dan Lawrence M. Friedman ${ }^{37}$ bahwa pada umumnya menyetujui menggunakan denda sebagai sanksi atas pelanggaran hukum pidana, sebab dengan denda, berart keuntungan yang telah diperoleh oleh si pelaku (business organization) akan menjadi hilang (karena didenda). Pidana yang demikian ini (denda) akan dapat mencegah perolehan keuntungan melalui kejahatan.

Namun, apa yang ditulis oleh Harry V. Ball dan Lawrence M. Friedman tersebut, berbeda dengan Balakrishnan. Menurut Balakrishnan ${ }^{38}$ memang pidana denda itu sesuai diterapkan terhadap perusahaan atau korporasi, karena korporasi tidak dapat dijatuhi pidána penjara. Akan tetapi, denda saja masih belum cukup. Karena, sanksi yang berupa pidana denda tidak akan pernah dirasakan sebagai hukuman. Anggapan, bahwa denda sebagai hukuman hanyalah di atas kertas. Untuk itu, perlu ada

${ }^{35}$ Hamy V. Ball and Lawrence M. Friedman, "Criminal Sanctions for Economic Offenses", dalam Norman Johnston, Leonard Savitz, Marvin E. Wolfgang, (ED), The Sociology of Punishment and Correction, Second Edition (New York: John Wiley \& Sons, Inc., 1970), him 318-319.

${ }^{36} \mathrm{Ibid}$. hlm 319.

${ }^{37}$ Harry V. Ball and Lawrence M. Friedman, "The Use of Criminal Sacntions in the Enforcement of Economic Legislation: A Sociological View", dalam Gilbert Geis and Robert F. Meier (ed), White-collar Crime: Offenses in Business, Polltics, and the Professions (New York: The Free Press, A Division of Macmillan Publishing Co., Inc., 1977), him 320.

${ }^{38}$ Balakrishnan, "Reform of Criminal in India Some Aspects", dalam Resource Material Series, No. 6, (Fuchu, Tokyo, Japan: UNAFEl, Oktober 1973), hlm 48. 
ketentuan khusus, seperti menghentikan kegiatan korporasi untuk sementara waktu dan untuk mengelola korporasi itu dilakukan oleh negara.

Mencari alternatif sanksi yang tepat untuk dikenakan terhadap korporasi, Kadish ${ }^{39}$ mengajukan alternatif berupa memberikan "cap" jahat kepada korporasi. Menurut Kadish, memberikan cap jahat itu dapat dilakukan seperti merusak nama baik korporasi dalam kegiatan bisnisnya, sehingga akan mempengaruhi keadaan ekonominya. Dengan sanksiyang berupa stigma atau cap itu, akan dapat mencegah korporasi melakukan kejahatan.

Di Indonesia, konsep yang ditawarkan oleh Kadish itu, pernah dilaksanakan oleh Jaksa Agung Sukarton Marmosudjono sekitar tahun 1990, yaitu penayangan wajah koruptor di televisi. Namun demikian, Barda Nawawi Arie ${ }^{40}$ mengkritisinya dengan mempertanyakan dasar yuridis dari penayangan tersebut. Menurut Barda Nawawi Arief apabila.penayangan koruptor itu dimaksudkan sebagai salah satu bentuk pelaksanaan putusan hakim, maka hal itu tidak ada dasar hukumnya dalam Undangundang No. 3 Tahun 1971. Karena pengumuman putusan hakim, dasarnya bukan Undang-undang No. 3 Tahun 1971, melainkan KUHP.

Konsep perlindungan korban dengan menggunakan sarana hukum pidana yang telah diuraikan di atas tadi, sasarannya adalah pada perlindungan terhadap calon korban agar tidak menjadi korban kejahatan ekonomi di bidang perbankan. Namun, karena dalam tulisan ini konsep perlindungan korban tidak saja ditujukan terhadap calon korban, tetapi juga perlindungan terhadap korban langsung sebagai akibat dari kejahatan yang dilakukan oleh bank (korporasi). Dengan konsep yang demikian, dimaksudkan agar ada keseimbangan perlindungan antara korban potensial dan korban langsung.

Dalam hubungan ini, Barda Nawawi Arief menulis ${ }^{41}$ bahwa konsep perlindungan korban dapat dilihat dari dua aspek. Pertama, dapat diartikan sebagai perlindungan hukum untuk tidak menjadi korban tindak pidana. Kedua, dapat diartikan sebagai perlindungan untuk memperoleh jaminan/santunan hukum atas kerugian orang yang telah menjadi korban tindak pidana. Menurut Barda Nawawi Arief, bentuk santunan itu dapat berupa pemulihan nama baik (rehabilitasi), pemulihan keseimbangan batin (seperti permaafan), pemberian ganti rugi (restitusi, kompensasi) dan santunan kesejahteraan sosial.

Di antara beberapa bentuk santunan tersebut, penulis menggarisbawahi bentuk pemberian ganti rugi yang meliputi restitusi atau kompensasi. Menurut Stephen.Schafer ${ }^{42}$

${ }^{39}$ Sanford H. Kadish, "Some Observations on the Use of Criminal Sacntions in Enforcing Economic Regulations", dalam Gilbert Geis and RobertF. Meier, (ed), White-collar Crime: Offenses in Business, Politics, and the Professions (New York: The Free Press, A Division of Macmillan Publishing Co., Inc., 1977), hlm 304.

${ }^{40}$ Barda Nawawi Arief, "Penayangan Koruptor pada Media TVRI Ditinjau dari segi Hukum Pidana", dalam Muladi dan Barda Nawawi Arief, Bunga Rampai Hukum Pidana (Bandung: Alumni, 1992), hlm 135-144.

${ }^{41}$ Barda Nawawi Arief, op.cit, hlm 60.

${ }^{42}$ Stephen Schafer, The Victim and His Criminal: A Study in Fungsional Responsibility (New York: Random House, 1968), hlm 112:113. 
istilah restitusi dan kompensasi, dalam penggunaannya sering dipertukarkan. Namun, di antara kedua bentuk ganti kerugian itu, Schafer lebih condong menggunakan restitusi terhadap korban. Menurut Schafer, ganti rugi kepada korban kejahatan seharusnya menjadi tanggung jawab pribadi pelaku (offender), tanggung jawab ini pada dasarnya juga merupakan bagian dari proses pemasyarakatan (correctional process). Berdasarkan sudut pandang ini, restitusi tidak semata ditujukan kepada orang yang telah dirugikan itu, akan tetapi pada saat yang sama juga membantu memasyarakatkan kembali dan rehabilitasi si pelaku, dan itu merupakan bagian dari pemidanaan.

Sejalan dengan pandangan Schafer, J.J.M. van Dijk, dkk. menulis ${ }^{43}$ bahwa tanggung jawab pelaku kepada korban, pada dasarnya merupakan upaya untuk menyelesaikan konflik antara pelaku dan korban dengan menggunakan sarana hukum pidana, karena pidana itu dapat dipandang sebagai pemuasan bagi korban. Namun demikian, upaya penyelesaian konflik itu masih tergantung sampai sejauh mana kerugian itu pada akhirnya diganti.

Sehubungan dengan itu, dalam Handbook on Justice for Victim, di mana pada bagian-
Restifution by offenders to victim and to the community, dikemukakan tujuan dari restitusi tersebut, antara lain: ${ }^{44}$ a). Restitusi harus digunakan untuk memberikan ganti kerugian atas kejahatan yang dilakukan terhadap korban dan untuk memberikan tanggung jawab pelaku yang dapat diterima oleh masyarakat, sehingga memberikan kesempatan yang besar bagi kemungkinan rehabilitasi. b). Restitusi merupakan sarana penting dalam peradilan pidana. Restitusi berusaha untuk membangun hubungan antara korban dan pelaku dalam upaya untuk meningkatkan rasa tanggung jawab pelaku terhadap korban dan masyarakat. Adapun ide dari restitusi tersebut, adalah juga untuk meningkatkan rasa tanggung jawab pribadi kepada korban.

Menurut Muladi45 penyelesaian masalah korban dalam kasus-kasus pidana, selain menimbulkan gerakan untuk lebih memperhatikan korban dalam access to justice, juga muncul gerakan untuk menumbuhkan apa yang dinamakan dengan restorative justiceyang menempatkan peradilan pada posisi mediator.

Konsep restorative Justice tersebut di dalam United Nations Office for Drug Control and Crime Prevention ${ }^{46}$ dinyatakan, restorative

${ }^{43}$ J.J.M. van Dijk, loc.cit.

${ }_{4}^{4}$ United Nations Office for Drug Control and Crime Prevention, Handbook on Justice for Victim, (New York: Centre for Intemational Crime Prevention, 1999), hlm 47. Purpose of restitution: a) restitution should be used to provide a way of offsetting some of the harm done to the victim and to provide a socially constructive way for the offender to be held accountable, while offering the greatest possible scope for rehabilitation; b) restitution is an important tool in criminal justice. ....restitution attempts to establish a relationship between the victim and the offender in an effort to raise the offender's sense of responsibility to the victim and to society. The idea of restitution is also to advance a sense of personal accountability to the victim.

${ }_{45}$ Muladi, Hak Asasi Manusia, Politik dan Sistem Peradilan Pidana (Semarang: Badan Penerbit Universitas Diponegoro, 1997), hlm 67.

${ }^{46}$ United Nations Office for Drug Control and Crime Prevention, Handbook on Justice for Victims (New York: Centre for Intemational Crime Prevention, 1999), him 42-43. 
justice merupakan sebuah 'istilah baru terhadap konsep lama. Seluruh sejarah' umat manusia, pendekatan restorative justice telah digunakan dalam memecahkan konflik antara para pihak dan memulihịkan perdamaian di masyarakat. Pendekatan-pendekatan retributive atau rehabilitative terhadap kejahatan dalam tahun-tahun terakhir ini dianggap sudah tidak memuaskan lagi. Karena itu, telah memberikan dorongan untuk beralih kepada pendekatan restorativejustice. Adapun kerangka dari restorative justice itu melibatkan pelaku, korban dan masyarakat dalam upaya untuk menciptakan keseimbangan, yaitu antara pelaku dan korban.

Sesuai dengan pandangan di atas, Adam Graycar, Director of Australian Institute of Criminology menulis ${ }^{47}$ bahwa dalam praktek restorative justice, teori reintegrative shaming sangat mendukung dalam penyelesain konflik melalui pendekatan restorative justice tersebut. Graycar, yang mengutip pendapat John Braithwaite mengenai teori reintegrative shaming, lebih lanjut menulis bahwa ada dua segi utama yang melekat pada proses restorative tersebut. Pertama, untuk mencapai keberhasilan reintegrasi itu, maka proses yang dilakukan harus melibatkan kehadiran dan peranserta masyarakat bagi dukungan terhadap pelaku dan korban. Kedua, adalah proses yang memerlukan adanya perasaan malu (shaming) sebagai suatu pencelaan (confrontation) atas perbuatan salah antara pelaku dan korban.'Proses melalui pendekatan restorative ini bertujuan; a) menjelaskan kepada pelaku bahwa perbuatan tersebut merupakan perbuatan yang tercela di masyarakat; b) dukungan dan menghargai seseorang walaupun perbuatannya tersebut merupakan perbuatan yang tercela. Dengan demikian, tujiuan dari program restorative tersebut, adalah mengembalikan pelaku'ke dalam masyarakat, agar dapat menjadi anggota masyarakat yang bertanggung jawab, mematuhi hukum dan menjunjung tinggi nilai-nilai dalam masyarakat.

Untuk itu menurut Muladi, ${ }^{48}$ model konsensus yang dianggap menimbulkan konflik baru harus digantikan dengan model asensus, karenanya dialog antara yang berselisih untuk menyelesaikan masalahnya, merupakan langkah yang sangat positif. Bertolak dari konsep ini, maka muncul istilah ADR yang dalam hal-hal tertentu menurut Muladi lebih memenuhi tuntutan keadilan dan efisien.

Namun yangperlu dibericatatan sehubungan dengan pendekatan melalui sarana ADR ini, yaitu sebagaimana yang ditulis oleh Mas Achmad Santosa $^{49}$ bahwa di Amerika Serikat sebagai negara tempat pertama kali dibangunnya $A D R_{1}$ dalam perkembangannya telah merubah konsep dari ADR menjadi DR, sehingga kata alternative dihilangkan. Alasannya, karena dengan ADR

\footnotetext{
${ }^{47}$ Adam Graycar, dalam Australian Institute of Criminology, trends and issues in crime and criminal justice, Bullying and Victimisation in School: A Restorative Justice Approach, No. 219, Pebruari 2002, hlm 2-3. http:l Murw.aic.gov.au

${ }^{48}$ Loc. cit.

${ }^{49}$ Mas Achmad Santosa, "Perkembangan Pelembagaan ADR di Indonesia", materi Pelatihan tentang Pilhan Penyelesaian Sengketa (Alternative Dispute Resolution/ADR) di Bidang Lingkungan, Kerjasama PPLH Lemlit UNDIP, ICEL, Asia Foundation dan Depkeh, Semarang, 10-13 April 1999, hlm 1-2.
} 
seolah dalam penyelesaian sengketa secara konsensual hanya dapat dilakukan di luar pengadilan. Padahal, kebutuhan pengembangan penyelesaian sengketa secara konsensual saat ini, juga diperlukan di dalam pengadilan.

Memang, pendekatan melalui șarana ADR ini, pada awalnya termasuk dalam wilayah hukum keperdataan, akan tetapi dalam perkembangannya digunakan pula dalam hukum pidana, yaitu sebagaimana tercantum dalam dokumen penunjang Kongres PBB ke-9 Tahun 1995 di Kairo, yaitu Dokumen AVCONF. $169 / 6^{50}$ bahwa untuk perkara-perkara pidana yang mengandung unsur fraud dan white-collar crime atau apabila terdakwanya korporasi, maka pengadilan seharusnya tidak menjatuhkan pidana, tetapi mencapai suatu hasil yang bermanfaat bagi kepentingan masyarakat secara menyeluruh dan mengurangi kemungkinan terjadinya pengulangan.

Dengan demikian, Pengembangan dari ADR ke DR tersebut, sesuai dengan Dokumen A/CONF. $169 / 6$ yang telah menempatkan konsep ini dalam hukum pidana. Ini berartj akan tetap memberi peran kepada pengadilan dalam menyelesaikan suatu perkara pidana sesuai prinsip Win-Win Solution dan bukan Win-Lose Solution. Mengenai prinsip Win-Win Solution ini, Covey menulis ${ }^{51}$ bahwa Win-Win atau Menang-Menang, berarti pemecahan masalah yang memungkinkan semua orang untung.
Dengan demikian, prinsip Samarsama Untung yang merupakan implementasi dari konsep restorative justice dan di dalamnya termasuk juga restitusi dari pelaku kepada korbannya adalah sesuai dengan perkembangan masa kini, sehingga ada kẹseimbangan atau kombinasi antara penyelesaian melalui perigadilan (court settlement) dan di luar pengadilan (out of court settement).

Untuk pembaharuan Undang-undang tentang Perbankan yang akan datang, relevan jika mempertimbangkan mencantumkan penyelesian perkara dengan prinsip Win-Win Solution ini dalam rumusan ketentuan pidananya. Karena, di satu sisi korban tetap mendapatkan perlindungan hukum berupa ganti kerugian (restitusi) dari pelaku, yang merupakan tanggung jawab pelaku (korporasi) kepada korbainnya, dan di sisi lain, pelaku (korporasi) wajib memenuhi tanggung jawabnya tersebut sesuai dengan hasil kesepakatan atau negosiasi antara pelaku dan korban dengan melibatkan pengadilan, karenanya apabila kewajiban sebagaimana telah disepakati itu tidak dijalankan atau tidak dipenuhi oleh pelaku (korporasi), maka pengadilan dapat memaksa pelaku untuk memenuhi kewajibannya itu, di samping juga pidanayang lebih berat akan dikenakan kepada pelaku.

Dalam konteks ini, relevan apabila merujuk kepada tulisan John C. Coffee. Menurut Coffee ${ }^{52}$ ketelitian dalam menjatuhkan pidana

${ }^{50}$ Barda Nawawi Arief, "Pemberdayaan Court Management Dalam Rangka Meningkatkan Fungsi Mahkamah Agung (Käjian dari Aspek Sistem Peradilan Pidana)", Makalah pada Seminar Nasional Pemberdayaan 1 Maret 2001, him 7-8.

${ }^{51}$ Covey, "The Seven Habits of Highly Effective People", (Terjemahan) (Covey Leadership Center, 1994), hlm 3.

52 John C. Coffee, "Corporate Criminal Responsibility", dalam Sanford H. Kadish, (ed), Encyclopedia of Crime and Justice, Volome 1 (New York: The Free Press, 1983), hlm 262. 
dengan pertimbangan akan lebih bermanfaat bagi korporasi mempunyai akibat-akibat lain yang diinginkan seperti antara lain, memastikan bahwa pelanggaran yang dilakukan oleh agent akan berakibat dengan penjatuhan pidana terhadap korporasi, dan pengadilan berwenang memerintahkan pemberian pidana ganti rugi kepada korban. Untuk itu, maka pengadilan dapat pula mempertimbangkan pengawasan yang dapat diimplementasikan melalui pidana berupa corporate probation. Dengan demikian, pengawasan terhadap korporasi melalui pidana corporate probation tersebut, adalah sebagai sarana untuk menjamin agar pidana yang telah dijatuhkan terhadap korporasi benar-benar dapat dilaksanakan dengan baik.

\section{Simpulan}

Berdasarkan uraian di atas, maka berikut ini dapat diambil kesimpulan sebagai berikut : 1. (a). Politik hukum pidana dalam hukum pidana positif masih berorientasi pada kepentingan pelaku, sehingga perlindungan terhadap korban (khususnya korban langsung) menjadi sangat lemah. Adanya politik hukum pidana yang demikian, karena dianutnya pertanggungjawaban pidana yang bersifat individual. (b). Subjek tindak pidana dalam Undang-undang tentang Perbankan terfokus pada manusia, bukan pada bank (korporasi) sebagai pelaku, sehingga tidak ada pertanggungjawaban pidana korporasi (bank) terhadap korban kejahatan ekonomi di bidang perbankan.

2. Konsep perlindungan korban kejahatan ekonomi di bidang perbankan dengan menggunakan hụkum pidana bertumpu pada tiga pilar dalam hukum pidana: Pertama: mengkriminalisasikan perbuatan yang berpotensi bagi timbulnya korban, merupakan langkah preventif. Perbuatanperbuatan tersebut meliputi: fraudulent misrepresentation; praktek bank dalam bank; pelanggaran BMPK (dalam Undang-undang tentang Perbankan masih belum tegas dinyatakan sebagai kejahatan); dan menyalahgunakan kewenangan baik untuk kepentingan pribadi maupun orang lain sebagai tindak pidana korupsi. Demikian juga dengan pengaturan korporasi sebagai subjek hukum pidana. Kedua: doktrin pertanggungjawaban pidana berdasarkan asas culpabilitas, jika pelakunya korporasi, dapat dikesampingkan atau diterobos dengan doktrin strict liability atau vicarious liability. Ketiga: perlindungan korban kejahatan ekonomi di bidang perbankan, tidak hanya perlindungan terhadap potential victim atau calon korban, melainkan juga perlindungan terhadap actual victim, sehingga akan menciptakan keseimbangan dalam hukum pidana antara pelaku dan korban, dan antara calon korban dan korban langsung.

Memformulasikan ancaman pidana denda yang tinggi tidak akan dapat mencegah korporasi (bank) melakukan kejahatan ekonomi di bidang perbankan tanpa dikombinasikan dengan altematif sanksi pidana lainnya seperti misalnya publicity sanction.

\section{Daftar Pustaka}

Arief, Barda Nawawi. "Masalah Pemidanaan Sehubungan dengan Perkembangan Delik-delik Khusus dalam Masyarakat Modern," dalam Muladi dan Barda Nawawi Arief, Teori-teori dan Kebijakan 
Pidana, Bandung: Alumni, 1984. "Penayangan Koruptor pada Media TVRI Ditinjau dari segi Hukum Pidana," dalam Muladi dan Barda Nawawi Arief, (ED), Bunga Rampai Hukum Pidana, Bandung: Alumni, 1992.

Kebijakan Hukum Pidana, Bandung: Citra Aditya Bakti, 1996.

Kebijakan Penegakan dan Pengembangan Hukum Pidana, Bandung: Citra Aditya Bakti, 1998.

Hukum , Masalah Penegakan

Penanggulangan Kejahatan, Bandung: Citra Aditya Bakti, 2001.

Balakrishnan. "Reform of Criminal Law in India: Some Aspects", dalam Resource Material Series No. 6, Fuchu, Tokyo, Japan: UNAFEI, 1973.

Ball, Harry V. and Lawrence M. Friedman. "Criminal Sanctions for Economic Offenses," dalam Norman Johnston, Leonard Savitz, Marvin E. Wolfgang, (ed), The Sociology of Punishment \& Correction, Second Edition, New York: John Wiley and Sons, Inc., 1970.

Criminal Sanctions in the Enforcement of Economic Legislation: A Sociological View, "dalam Gilbert Geis dan Robert F. Meier, (ED), White-collar Crime: Offenses in Business, Politics, and the Professions, New York: The Free Press,
1977.

Clinard, Marshall B. and Peter C. Yeager. Cor-. porate Crime, New York: The Free Press, 1980.

Corporate Ethics

and Crime, London: Sage Publication, 1983.

Coffee, Jr., John C. "Corporate Criminal Responsibility," dalam Sanford H. Kadish, (ED), Encyclopedia of Crime and Justice, Volome 1, New York: The Free Press, 1983.

Covey. The Seven Habits of Highly Effective People, (Terjemahan), Covey Leadership Center, 1994.

Gillies, Peter. Criminal Law, Second Edition, Sydney: The Law Book Company, 1990.

Heaton, Russel. Criminal Law, Cases \& Materials, Second Edition, London: Blackstone Press Limited, 1998.

Kadish, Sanford H. "Some Observations on the Use of Criminal Sanctions in Enforcing Economic Regulations," dalam Gilbert Geis dan Robert F. Meier, (ED), Whitecollar Crime: Offenses in Business, Politics, and the Professions; New York: The Free Press, 1977.

Moeljatno. Asas-asas Hukum Pidana, Yogyakarta: Liberty, 1980.

Muladi dan Barda Nawawi Arief. "Pidana dan Pemidanaan," dalam Muladi dan Barda Nawawi Arief, Teori-teori dan Kebijakan Pidana, Bandung: Alumni, 1984. 
___ "Proyeksi Hukum Pidana Materiil Indonesia di masa Mendatang," Pidato Pengukuhan Jabatan Guru Besar dalam bidang IImu Hukum, Fakultas Hukum UNDIP, Semarang, 24 Februari, 1990.

- Hak Asasi Manusia, Politik dan Sistem Peradilan Pidana, Semarang: Badan Penerbit Universitas Diponegoro, 1997.

Sahetapy. Teori Kriminologi, Sebuah Pengantar, Bandung: Citra Aditya Bakti, 1992.

Schafer, Stephen. The Victim and His Criminal: A Study in Functional Responsibility, New York: Random House, 1968.

Smith, J.W. The World's Wasted Wealth, The Political Economy of Waste, Kalispell, Montana: New Worlds Press, 1989.

Sudarto. Hukum dan Hukum Pidana, Bandung: Alumni, 1983 a.

- - Hukum Pidana dan Perkembangan Masyarakat: kajian terhadap pembaharuan hukum pidana, Bandung: Sinar Baru, 1983 b.

Tambunan, Tulus. Krisis Ekonomi, dan Masa Depan Reformasi, Jakarta: Lembaga Penerbit Fakultas Ekonomi Universitas Indonesia, 1998.

Widjanarto. Hukum dan Ketentuan Perbankan di Indonesia, Edisi III, Jakarta, Grafiti, 1997.

Perundang-undangan

Undang-undang Nomor 31 Tahun 1999 tentang Pemberantasan Tindak Pidana Korupsi (Lembaran Negara Tahin 1999 Nomor 140).

Undang-undang Nomor 20 Tahun 2001 tanggal 21 Nopember 2001 (Lembaran Negara Tahun 2001 Nomor 134) tentang Perubahan atas Undangundang Nomor 31 Tahun 1999 tentang Pemberantasan Tindak Pidana Korupsi (Lembaran Negara Tahun 1999 Nomor 140).

Undang-undang Nomor 10 Tahun 1998 tentang Perubahan Undang-undang Nomor 7 Tahun 1992 tentang Perbankan (Lembaran Negara Tahun 1998 Nomor 182).

Keppres Nomor 26 Tahun 1998 tentang Jaminan Terhadap Kewajiban Pembayaran Bank Umum, Tanggal 26 Januari 1998 (Lembaran Negara Tahun 1998 Nomor 29).

Peraturan Bank Indonesia Nomor 2/1/PBI/2000 tentang Penilaian Kemampuan dan Kepatutan (Fit and Proper Test) (Lembaran Negara Tahun 2000 Nomor 3 dan Tambahan Lembaran Negara Nomor 3922).

Rancangan Undang-undang tentang Kitab Undang-undang Hukum Pidana, 1999. 2000.

Undang-undang Nomor 7/Drt./1955 tentang Tindak Pidana Ekonomi (Lembaran Negara Tahun 1955 Nomor 27).

Instrumen Internasional

United Nations, Economic and Social Coun- 
cil, Commission on Crime Prevention and Criminal Justice, Vienna, 21-30" April 1992.

United Nations Office for Drug Control and Crime Prevention, 1999, Handbook on Justice for Victims, New York: Centre for International Crime Prevention.

\section{Makalah Seminar dan Penataran.}

International Meeting of Experts on the Use of Criminal Sanction in the Protection of Environment, Internationally, Domestically and Regionally, Diselenggarakan di Portland, Oregon USA, 19-23 Maret 1994. Disampaikan kembali oleh Barda Nawawi Arief, sebagai bahan Penataran Hukum Pidana dan Kriminologi, di Hotel Siranda, Semarang, 3-15 Desember 1995.

Reksodiputro, Mardjono, "Hukum Positif Mengenai Kejahatan Ekonomi dan Perkembangannya di Indonesia, disampaikan dalam Seminar: Kejahatan Ekonomi di Bidang Perbankan, Diselenggarakan oleh Bank Indonesia, Jakarta, 4-7 Januari 1993.

Santosa, Mas Achmad, "Perkembangan Pelembagaan ADR di Indonesia," Materi Pelatihan tentang Pilihan Penyelesaian Sengketa (Alternative Dispute Resolution/ADR) di Bidang Lingkungan, Kerjasama PPLH Lemlit UNDIP, ICEL, Asia Foundation dan Depkeh, Semarang, 10-13 April 1999.

\section{Terbitan Khusus}

Bank Indonesia, Bantuan Likuiditas Bank Indonesia (BLBI), Lampiran 9, Petikan Laporan Panja Komisi IX DPR-RI, tanggal 6 Maret 2000, http:/l www.bi.go.id/bank indonesia2

Center for Banking Crisis, Buku Puth, Jilid I, Jakarta, 1999.

Listyorini. Wartawan Suara Pembaruan, "Menyoal Fungsi BI sebagai Lender of the Last Resort," dalam Bank Indonesia, Bantuan Likuiditas Bank Indonesia, http://www.bi.go.id/bank indonesia2/ spesial/blbil

Jurnal

Australian Institute of Criminology, trends \& issues in crime and criminal justice, "Bullying and Victimisation in Schools: A Restorative Justice Approach," No. 219, February 2002, http://www.aic.gov.au

Jumal Hukum Bisnis, Vol. 6, 1996.

Majalah

Abdullah, Bachtiar, Dalam Prospek, I Juni 1991.

Majalah Forum Keadilan, Nomor 19, 7 Januari 1993.

Majalah Forum Keadilan, "Peninggalan Masa Lalu yang Bikin Geram," No. 22, 3 September 2000

Harian Jawa Pos, 15 Oktober 1996 